\title{
Corrosion Behaviour of Steels in Nigerian Food Processing Environments
}

\section{${ }^{*}$ STANLEY UDOCHUKWU OFOEGBU; ${ }^{2}$ PEARL UGOCHI OFOEGBU; ${ }^{3}$ SIMEON I. NEIFE; ${ }^{3}$ BONIFACE A, OKORIE}

\author{
${ }^{1}$ Department of Materials and Metallurgical Engineering, ${ }^{2}$ Department of Biotechnology, \\ Federal University of Technology, P.M.B 1526, Owerri, Nigeria \\ ${ }^{3}$ Department of Metallurgical and Materials Engineering, \\ Enugu State University of Science and Technology, P.M.B 1660, Enugu, Nigeria \\ "Corresponding Author Email:stanleyofoegbu@yahoo.com
}

\begin{abstract}
The corrosion of mild steel (uncoated), galvanized steel and stainless steel (304L) have been studied using the weight loss method over a period of 98 days with measurements made at 14 days' interval in ground melon (locally called egusi), cassava pulp, mashed palm fruit, tomato pulp, and black-eyed bean pulp respectively. The results obtained show that the average corrosion rates of 304 stainless steel, galvanized steel and mild steel are in ground melon $\left(1.98 \times 10^{-3}, 1.81 \times 10^{-2}, 2.65 \times 10^{-2}\right) \mathrm{mpy}$; in cassava pulp $\left(3.68 \times 10^{-3}, 7.09 \times 10^{-1}\right.$, $\left.5.64 \times 10^{-1}\right) \mathrm{mpy}$; in mashed palm-fruit $\left(4.75 \times 10^{-3}, 2.38 \times 10^{-1}, 2.83 \times 10^{-3}\right) \mathrm{mpy}$; in bean pulp $\left(3.07 \times 10^{-3}, 9.25 \times\right.$ $\left.10^{-1}, 1.16\right) \mathrm{mpy}$; and in tomato pulp $\left(5.46 \times 10^{-3}, 6.99 \times 10^{-1}, 7.83 \times 10^{-2}\right)$ mpy respectively. Normalizing these corrosion rates data with respect to that of stainless steel in each environment showed that in ground melon galvanized steel and mild steel had corrosion rates 91.41 and 13.38 times that of stainless steel; in cassava pulp 183.68 and 148.11 times; in mashed palm-fruit 50.08 and 58.58 times; in bean pulp 301.3 and 377.85 times; and in tomato pulp 128.2 and 14.34 times respectively. Presentation of the average corrosion rate and average specific weight loss of mild steel and galvanized steel, relative to that of stainless steel enables an easier assessment of the corrosion resistance of these substitute steels, which is envisaged will be of immense benefit to the local food and quality regulatory agencies and food processing equipment fabricators. It is our desire that these results provide the scientific community with a relatively long term corrosion data on Nigerian food processing media. @ JASEM
\end{abstract}

Corrosion which is the deterioration of a material of construction or its properties due to reaction with the environment (Budinski, 1983), is a problem in a lot of industries and is even a greater challenge in the food processing and pharmaceutical industries, where in addition to the loss of production time for maintenance and risk of equipment failure, there exists the additional risk of product contamination by corrosion products which may result in food poisoning. As a consequence food processing machinery, in spite of cost considerations have been as a standard constructed using stainless steels. Whereas most industrial food processing equipment are fabricated/specified in stainless steel, other materials like tinned copper had been employed successfully (Fontana, 1987) and the suitability of other materials especially for specific environments should not be overlooked. Over the years in Nigeria, there has been an increase in the local fabrication of food processing equipment using materials that are not stainless steel, thus reducing cost, making these attractive to the food processing needs of the rural small scale farmers mainly due to price considerations. These have been fabricated in a variety of metallic materials ranging from mild steel (coated and uncoated), galvanized steel to different grades of stainless steel.

The chemical composition of the metals and more importantly the food processing environment is crucial as it will to a large extent determine the possible corrosion reactions, the corrosion product formed and hence its ability to adhere to the metal and reduce metal loss or enter the food media, exposing more metallic surface and enhance metal loss. Food stuff contain a lot of chemicals (mainly organic), and which when allowed to stand can become substrates for much microbial activity which may lead to the production of chemical products that may be more aggressive to metallic material. The organic acids present in foods are the most important corrosion agents. The effects of these chemicals can be influenced by the environmental conditions of processing such as temperature, flow rate, viscosity of the food media, and presence of stresses in the system. Exact analysis of the constituents of food stuff is a challenge due to their very complex compositions (Purseglove, 1981).

Most foods are acidic (McSwane et al, 2003; Bailey and Bailey,1995; Reger et al 2009) and since steels are active in acidic medium are susceptible to corrosion in food processing media. For instance, the processing of cassava tubers yields hydrogen cyanide with most varieties reported to contain $15-400 \mathrm{mg}$ cyanide $/ \mathrm{kg}$ fresh weight and a few varieties containing up to1300-2000mg cyanide/kg (fresh weight) in the tubers and $1000-2000 \mathrm{mg} / \mathrm{kg}$ cyanogenic glucosides on a dry matter basis in the cassava leaves ( Padmaja and Steinkraus, 1995). In cassava products, cyanide exist in three forms; (a) as the glucoside (linamarin and lotaustralin), (b) the cyanohydrin and (c) as the free hydrocyanic acid (HCN) (Tewe, 1991). HCN is a weak acid and is normally not corrosive, however it exhibits a corrosive effect under two special conditions; in solution with water $\mathrm{HCN}$ cause transcrystalline stress cracking of carbon steels under stress even at room 
temperature and when in dilute solution in water containing $\mathrm{H}_{2} \mathrm{SO} 4, \mathrm{HCN}$ severely corrode steel above $40^{\circ} \mathrm{C}$ and stainless steels above $80^{\circ} \mathrm{C}$ (Maxwell, 2004). The corrosion effect of cassava fluid on steel has been the focus of a lot of research efforts (Jekayinfa et al, 2009; Loto and Atanda ,1998; Oluwadare and Agbaje ,2007; Oluwole et al., 2009) Tomato is acidic, with most varieties having $\mathrm{pH}$ below 4.5 as it contains a cocktail of organic acids. The major organic acids present are citric acid and to a less extent malic acid, in addition to several carboxylic acids, sugar acids and alicyclic acids (Yilmaz, 2001). The ripe oil palm fruit (Elaeis guineensis) contains in the oily mesocarp, fat of composition $70-75 \%$ of dry matter, which consists of $39-52 \%$ oleic acid, $32-45 \%$ palmitic acid, $5-11 \%$ linoleic acid, 2-16\% stearic acid and 1-6\% myristic acid (Asiedu, 1992). Egusi seed (Citrullus lanatus) is reported (Jack, 1972) to comprise 50\% oil and $35 \%$ protein with amino acids analysis (Ojieh et al, 2008) of the protein indicating $9 \%$ of arginine, $4.8 \%$ isoluecine, $4.2 \%$ luecine, $3.2 \%$ phenylalanine, $16.9 \%$ glutamic acid and $16.3 \%$ aspartic acid per $100 \mathrm{~g}$ of protein.

\section{MATERIALS AND METHODS}

Forty-five samples of each type of steel was cut from metal sheets to dimensions of $(25 \times 50 \times 1.15) \mathrm{mm}$ for stainless steel, $(24.5 \times 50 \times 0.9) \mathrm{mm}$ for galvanized steel, and $(24 \times 50 \times 1) \mathrm{mm}$ for mild steel, with a $3 \mathrm{~mm}$ diameter hole drilled towards one longitudinal end for suspension in the test media. The sharp edges arising from the cutting and drilling steps were smoothened with a hand file. Next the specimens were cleaned in acetone, dried, weighed with an analytical balance to an accuracy of $1 / 10^{\text {th }}$ of a milligram to obtain the initial weights of the test coupons, labeled and polypropylene strings attached for suspension in the media.

The five indigenous food environments employed in this study; ground melon (locally called egusi (Citrullus lanatus)), cassava pulp (Manihot esculenta), mashed palm fruit (Elaeis guineensis), tomato pulp (Lycopersicon esculentum), and blackeyed bean pulp (Vigna unguiculata unguiculata), were prepared as follows. The melon environment was prepared by grinding $1500 \mathrm{~g}$ of the bare melon seeds. The cassava pulp environment was prepared by peeling $1500 \mathrm{~g}$ of freshly harvested cassava tubers, washing and then grinding to fine pulp taking care not to lose any water. The mashed palm fruit environment was prepared by boiling $1500 \mathrm{~g}$ of palm nuts until they become tender, and then pounding in a mortar with a pestle until (as done in the local extraction of oil) until the oil containing mesocarp become very fine in texture. The bean pulp environment was prepared by soaking $1500 \mathrm{~g}$ of the black-eyed beans in cold water for about 10 minutes , washing off the transparent seed cover (the testa), and then grinding with a blender with the addition $250 \mathrm{ml}$ of water to obtain a watery paste. The tomato pulp environment was prepared by grinding $1500 \mathrm{~g}$ of fresh tomatoes with a blender to a fine watery consistency.

The food processing environments thus prepared or simulated were poured into plastic containers and labeled. Nine specimens of each of the three types of steels used in the study were immersed in these five different food media respectively. Every 14 days samples of each type of steel is removed from each food media, observed, washed in running water with a rubber bung to remove corrosion products, washed in ethanol, and then acetone, dried and weighed to determine the final weight, from which the total weight loss, specific weight loss (weight loss per unit exposed area) and consequently the corrosion rate is computed.

\section{RESULTS AND DISCUSSIONS}

The results obtained show that the average corrosion rates of 304 stainless steel, galvanized steel and mild steel are in ground melon $\left(1.98 \times 10^{-3}, 1.81 \times 10^{-2}\right.$, $\left.2.65 \times 10^{-2}\right) \mathrm{mpy}$; in cassava pulp $\left(3.68 \times 10^{-3}, 7.09 \times\right.$ $\left.10^{-1}, 5.64 \times 10^{-1}\right) \mathrm{mpy}$; in mashed palm-fruit $(4.75 \mathrm{x}$ $\left.10^{-3}, 2.38 \times 10^{-1}, 2.83 \times 10^{-3}\right) \mathrm{mpy}$; in bean pulp (3.07 $\left.\mathrm{x} 10^{-3}, 9.25 \times 10^{-1}, 1.16\right) \mathrm{mpy}$; and in tomato pulp $\left(5.46 \times 10^{-3}, 6.99 \times 10^{-1}, 7.83 \times 10^{-2}\right) \mathrm{mpy}$ respectively. Normalizing these corrosion rate results (Table 1) with respect to that of stainless steel in the respective media enable easy comparison of how fast the substitute materials corrode in each media relative to $304 \mathrm{~L}$ stainless steel. Manipulation of corrosion data in this way, is believed to be suited to the the equipment fabricator, and shows that in ground melon galvanized steel and mild steel had corrosion rates 91.41 and 13.38 times that of stainless steel; in cassava pulp 183.68 and 148.11 times; in mashed palm-fruit 50.08 and 58.58 times; in bean pulp 301.3 and 377.85 times; and in tomato pulp 128.2 and 14.34 times respectively. Since the corrosion in food processing environment is usually more concerned with product contamination than with equipment failure, the presentation of corrosion data, in a form that gives the knowledge of the quantity of metal likely to be passed into the product as a result of corrosion is preferable. In this regard the corrosion data has been presented in mpy (mils per year) and also in terms of the (specific metal loss per unit time in $\mathrm{mg} / \mathrm{cm}^{2} /$ day) (Fig.3) to indicate the quantity of metal getting into the food (or whatever product) per unit area of the metal exposed per unit time. This has the benefit that with a knowledge of the chemical composition of the metal or alloy and assuming a uniform corrosion of all the constituent elements in the alloy, the elemental contamination in the food (or 
whatever product) can be estimated. The specific metal loss into the food media was recorded to be for stainless steel, galvanized steel and mild steel $(1.15 \mathrm{x}$ $\left.10^{-3}, 6.84 \times 10^{-2}, 1.19 \times 10^{-2}\right) \mathrm{mg} / \mathrm{cm}^{2} /$ day in ground melon; in cassava pulp $\left(1.05 \times 10^{-3}, 1.57 \times 10^{-1}, 1.96\right.$ $\left.\times 10^{-1}\right) \mathrm{mg} / \mathrm{cm}^{2} /$ day; in mashed palm-fruit $\left(1.53 \times 10^{-}\right.$ $\left.{ }^{3}, 5.67 \times 10^{-2}, 7.74 \times 10^{-2}\right) \mathrm{mg} / \mathrm{cm}^{2} /$ day; in bean pulp $\left(1.34 \times 10^{-3}, 2.4 \times 10^{-1}, 1.89 \times 10^{-2}\right) \mathrm{mg} / \mathrm{cm}^{2} /$ day, and in tomato pulp $\left(1.82 \times 10^{-3}, 1.3 \times 10^{-1}, 1.91 \times 10^{-2}\right)$ $\mathrm{mg} / \mathrm{cm}^{2} /$ day respectively. Normalization of these data, with respect to that of stainless steel shows that in metal ingress per $\mathrm{cm}^{2}$ per day of galvanized steel and mild steel in ground melon is 59.5 and 10.31 times that of stainless steel; in cassava pulp 149.68 and 186.59 times; in mashed palm-fruit 37.02 and 50.57 times; in bean pulp 179.29 and 14.07 times and in tomato pulp 71.17 and10.49 times respectively.

Table 1. Normalized average specific weight loss and average corrosion rates based on 304 stainless steel showing how many times mild steel and galvanized steel corrode in the different media with respect to stainless steel.

\begin{tabular}{|l|l|r|r|l|r|r|}
\cline { 2 - 7 } \multicolumn{1}{c|}{} & \multicolumn{3}{l|}{ Normalized Soecific Weight Loss } & \multicolumn{2}{l|}{ Normalized Corrosion Rates } \\
\hline ENVIRONMENTS & $304 \mathrm{~L}$ & $\begin{array}{l}\text { MILD } \\
\text { STEEL }\end{array}$ & $\begin{array}{l}\text { GALVANIZED } \\
\text { STEEL }\end{array}$ & $\mathbf{3 0 4 L}$ & $\begin{array}{l}\text { GALVANIZED } \\
\text { STEEL }\end{array}$ & $\begin{array}{l}\text { MILD } \\
\text { STEEL }\end{array}$ \\
\hline GROUND MELON & 1.00 & 10.31 & $\mathbf{5 9 . 5}$ & 1.00 & 91.41 & 13.38 \\
\hline CASSAVA PULP & 1.00 & 186.59 & 149.68 & 1.00 & 183.68 & 148.11 \\
\hline MASHED PALM-FRUIT & 1.00 & 50.57 & $\mathbf{3 7 . 0 2}$ & 1.00 & $\mathbf{5 0 . 0 8}$ & $\mathbf{5 8 . 5 8}$ \\
\hline BEAN PULP & 1.00 & 14.07 & 179.29 & 1.00 & 301.3 & $\mathbf{3 7 7 . 8 5}$ \\
\hline TOMATO PULP & 1.00 & 10.49 & 71.17 & 1.00 & 128.02 & 14.34 \\
\hline
\end{tabular}

Visual examination of the coupons after exposure indicated uniform corrosion in all the three steels in all the food processing environments studied, though in galvanized steel a random corrosion of the zinc coating was observed until all was stripped off after which uniform corrosion of the carbon steel base commenced. No visible corrosion product was observed in the stainless steel, only a slight loss in luster was evident. In the mild steel brownish corrosion products were observed. The galvanized steel exhibited different forms of corrosion products in different environments. In the tomato pulp, adherent scale was formed all over the surface, in ground melon the coupons were encapsulated by an oily gelatinous white deposit which was not easy to wash off. On washing off this coating the zinc coating was observed to have degraded in a small area which increased with increased exposure time. In the mashed palm fruit environment, the same gelatinous coating was observed though it was thin, and even after 98 days' exposure most of the zinc coating on the galvanized steel was intact. In the bean pulp environment, galvanized steel suffered the severest attack with total loss of the zinc coating before the first monitoring interval (14 days). Analysis of the adherent deposits observed in galvanized steel in tomato pulp indicated the presence of hydrated iron (iii) hydroxide and zinc chloride. In the bean pulp, examination of the corrosion product indicated the presence of a mixture of iron oxides, hydroxides and sulphide.

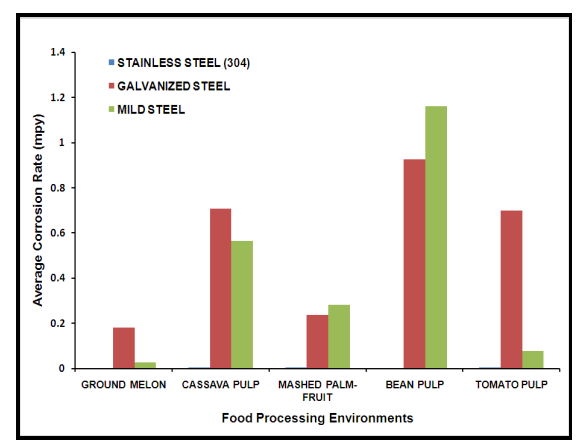

Fig.1. Bar chart showing the average corrosion rate (mpy) for the three steels in each of the food processing environments.

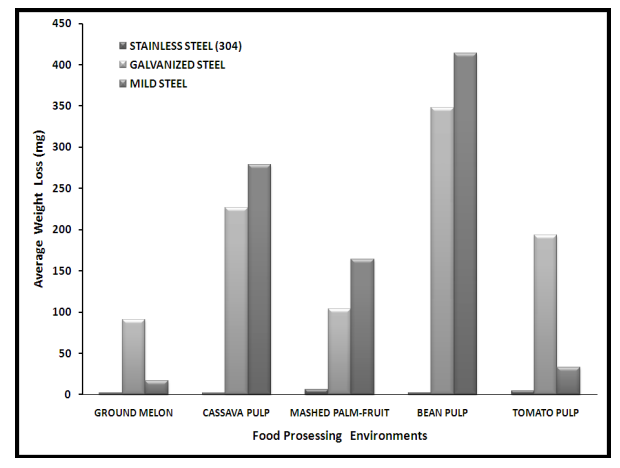

Fig.2. Bar chart showing the average weight loss (mg) for the three steels in each of the food processing environments. 


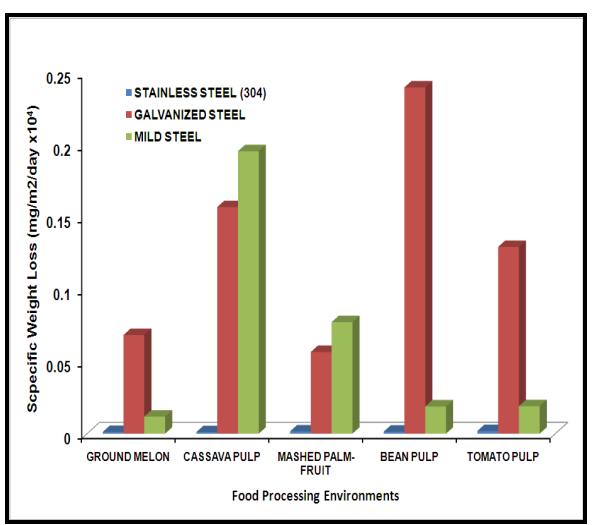

Fig.3. Bar chart showing the specific weight loss $\left(\mathrm{mg} \mathrm{m}^{-2} \mathrm{day}^{-1}\right)$ for the three steels in each of the food processing environments.

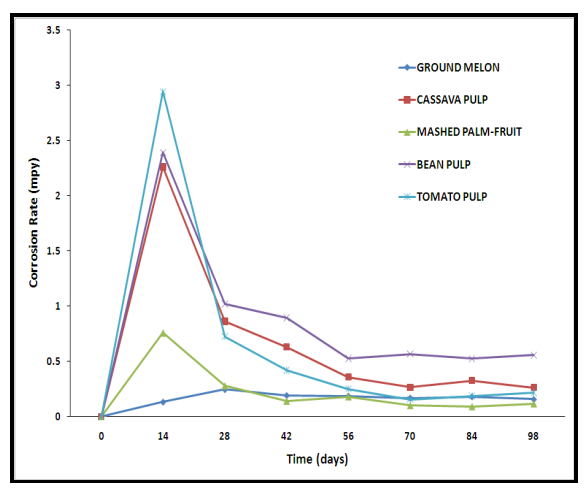

Fig.4. Plot of corrosion rate (mpy) Vs time (days) of galvanized steel in the food processing environments.

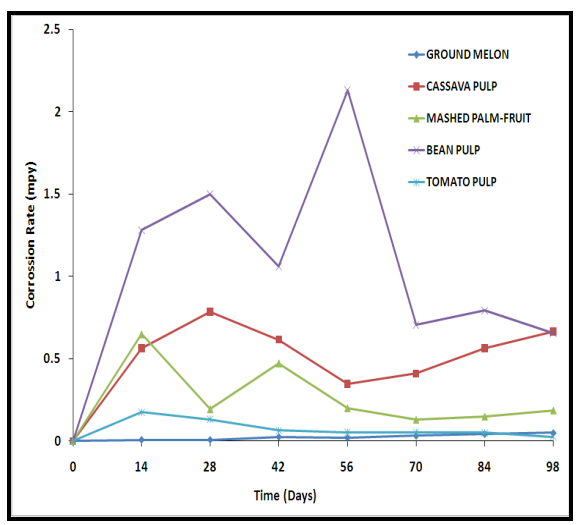

Fig.5. Plot of corrosion rate (mpy) Vs time (days) of mild steel in the food Processing environments.

It is observed that the corrosion rate was generally lower for the two oily food processing environments; ground melon (locally called egusi (Citrullus lanatus)), and mashed palm fruit (Elaeis guineensis), than for the water based ones for the three steels studied. This is believed to be gradual build up of oily corrosion products which inhibited further corrosive activity. As expected the corrosion rates for stainless steel was negligible in all the food processing environments while the bean pulp environment was most corrosive to mild steel and galvanized steel. The highest corrosion activity was observed in the galvanized steel in the bean pulp, then in cassava pulp and tomato juice environments within the initial twenty eight days, by which time all the zinc coating on the galvanized steel had been stripped off.

The pasty and gelatinous precipitates observed in galvanized steel in mashed palm fruit and ground melon is believed to consist mainly of a mixture of mainly zinc soaps and possibly some zinc hydroxides based on the observation of the properties of the coating and published work on synthesis and characterization of zinc metallic soaps(Lower, 1982 ; Landau, 2000) . For instance zinc stearate has been described as a zinc soap, insoluble in polar solvents, containing no electrolyte and possessing a hydrophobic effect (Corbeil and Robinet, 2002). These metal soaps must have been formed by the (DMR) direct metal reduction process in which according to Peultier et al (2003), the organic acids (palmitic acid $\mathrm{C}_{16} \mathrm{H}_{32} \mathrm{O}_{2}$, stearic acid $\mathrm{C}_{18} \mathrm{H}_{36} \mathrm{O}_{2}$, oleic acid $\mathrm{C}_{18} \mathrm{H}_{34} \mathrm{O}_{2}$,etc) react directly with zinc on the surface of the galvanized steel with lower molecular weight organic acids and moisture catalyzing the reaction according to the equation below which is receiving attention as a possible means of achieving conversion coatings on zinc.

$$
2 \mathrm{RCOOH}+\mathrm{Zn} \rightarrow \mathrm{Zn}(\mathrm{OOCR})_{2}+\mathrm{H}_{2}
$$

Galvanized steel when in contact with acidic foods is aggressively attacked by the acid species to yield zinc salts of the organic acids present (palmitic, stearic,oleic and myristic acids) otherwise known as metallic soaps, which are readily absorbed by the body. This explains why the galvanizing was quickly lost in the more acidic media. This is evident in the very high specific weight loss for galvanized steel recorded in this media. the In conclusion, it is obvious that the use of galvanized steel for fabricating food processing equipment is not advisable from a corrosion point of view, as it suffered more corrosion attack than mild steel in all the food processing environments studied except in the mashed palm fruit environment where it had slight advantage over mild steel, which cannot be justified by the higher cost of galvanized steel. In addition, the food environments studied aggressively attacked the galvanized coating on the galvanized steel, after which the corrosion rate slowed down to follow the trend observed in mild steel.

The results obtained show that (a) generally mild steel possesses better corrosion resistance than galvanized steel in the Nigerian food processing 
environments (except) in the bean pulp environment (b) as a consequence the use of galvanized steel for the construction if food processing machinery is not beneficial from the corrosion and economic point of view, (c) generally the ground melon environment was the least corrosive of the food processing environments studied while the bean pulp environment was the most aggressive to all the three steels under study except stainless steel for which tomato pulp was most aggressive to.

\section{REFERENCES}

Asiedu JJ ; (1992) Processing Tropical Crops, A Technical Approach. Macmillian London

Bailey PS ; Bailey CA.(1995) Organic chemistry: A Brief Survey of Concepts and Applications. Prentice Hall.

Budinski KG (1983) Engineering Materials, Properties and Selection. Reston Publishing Company Inc. A Prentice-Hall Company

Corbeil M ; Robinet L ; (2002) X-ray Diffraction Data of Selected Metal Soaps. Powder Diffraction. 7 (1) : 52-60.

Fontana MG (1987) Corrosion Engineering $3^{\text {rd }}$ Edition. McGraw-Hill Book Company. New York.

Jack TJ ; (1972) Cucurbit Seeds: 1. Characterization and Uses of Oils And Proteins. A Review. Economic Botany 26(2): pp 135-141.

Jekayinfa S.O., Waheed M.A., Adebiyi K.A., Adebiyi F.T., (2005) Effect of Cassava Fluid on Corrosion Performance of Mild Steel. AntiCorrosion Methods and Materials,. 52 (5), pp.286 $-292$

Landau M ; (2000) Driers and Metallic Soaps. KirkOthmer Encyclopedia of Chemical Technology. John Wiley \& Sons, Inc

Loto C.A and Atanda P.O (1998) Corrosion of Mild Steel in Cassava Juice. Journal of Corrosion Preven. Control

Lower ES ; (1982) Zinc Stearate : Its Properties and Uses. Pigment \& Resin Technology 11, 9-14.
Maxwell GR ; (2004) Synthetic Nitrogen Products: A Practical Guide to the Products and Processes. Springer USA.

McSwane D ; McSwane DZ ; Rue NR ; Linton R (2003) Essentials of Food Safety and Sanitation. Prentice Hall.

Ojieh GC ; Oluba OM ; Ogunlowo YR ; Eidangbe GO ; Orole RT ; (2008) Compositional Studies of Citrullus lanatus (Egusi Melon) Seed. The Internet Journal of Nutrition and Wellness..6 (1):

Oluwadare G.O and Agbaje O. (2007) Corrosion of Steel in Reinforced Concrete in Cassava Juice Journal of Applied Sciences 7 (17) 2474-2479

Oluwole O.O., Atanda P.O, Odekunbi O.A.,

Odegbaju E. (2009) Corrosion Behavior of 18/8 Stainless Steel and Nickel-Plated Low Carbon Steel in Cassava Fluid Journal of Minerals \& Materials Characterization \& Engineering, 8 (10), pp.803-811,

Padmaja G ; Steinkraus KH (1995) Cyanide Detoxification in Cassava for Food and Feed Use. Critical Reviews in Food Science and Nutrition. 35 (4) : 299 - 339.

Peultier J ; Rocca E ; Steinmetz J ; (2003) Zinc Carboxylating: A New Conversion Treatment of Zinc. Corrosion Science 45 (8) : 1703-1716.

Purseglove JW (1981) Tropical Crops: Dicotyledons. Longman Reprint 1981.

Reger DL; Goode SR ; Ball DW (2009) Chemistry: Principles and Practice. Thomson Brooks/Cole

Tewe OO ; (1991) Detoxification of Cassava Products and Effects of Residual Toxins on Consuming Animals. In: Machin, D., Nyvild, S. (Eds.), Roots, Tubers, Plantains and Bananas in Animal Feeding. FAO Anim. Prod. Health Paper No. 95, pp. 81-95.

Yilmaz E ; (2001) The Chemistry of Fresh Tomato Flavor Turk J Agric For 25 : 149-155. 